\title{
INTEGRATED FUZZY AHP AND WEIGHTED-FUZZY GOAL PROGRAMMING APPROACH TO SOLVE SUPPLIER SELECTION PROBLEM WITH SUBJECTIVE FACTORS
}

\author{
Annas Singgih Setiyoko*, Udisubakti Ciptomulyono ${ }^{\ddagger}$, dan I Ketut Gunarta ${ }^{\ddagger}$
}

\begin{abstract}
ABSTRAK
Proses seleksi pemasok menggunakan metode fuz:y goal programming (FGP) menunjukkan belum adanya preferensi pengambil keputusan terhadap setiap goals. Maka untuk mengakomodasi preferensi pengambil keputusan, dalam penelitian ini preferensi diekspresikan dengan memberikan bobot pada furæy goals, sehingga metode yang dikembangkan disebut weighted furay goal programming (WFGP). Metode ini digunakan untuk memecahkan permasalahan seleksi pemasok internasional. Fungsi objectives yang dikembangkan adalah minimasi persentase cacat, minimasi late delivery, minimasi harga pembelian, dan maksimasi business relationship. Fungsi tujuan maksimasi business relationship ditujukan agar pemasok mendapatkan perolehan alokasi yang sebanding dengan nilai business relationship-nya. Fungsi kendala yang dipertimbangkan diantaranya adalah total demand, kapasitas pasokan maksimal pemasok, harga pembelian berdasarkan owner estimate, dan jumlah order minimal yang disyaratkan pemasok. Penilaian kriteria-kriteria yang terdapat dalam faktor business relationship menggunakan variabel linguistik sehingga penilaiannya bersifat kualitatif. Fuz:y analytic bierarchy process (FAHP) digunakan untuk mengkuantifikasi sifat kualitatif sehingga diperoleh konstanta numerik pada fungsi objective business relationship. Pendekatan dengan metode WFGP menghasilkan solusi yang lebih mewakili preferensi pengambil keputusan pada goals yang dipentingkan bila dibandingkan dengan metode FGP. Hal ini ditunjukkan dengan keselarasan antara nilai goals terbobot dengan capaian pada goals terbobot.
\end{abstract}

Kata kunci: fuzzy goal programming, weighted, fuzzy analytic bierarchy process, seleksi pemasok.

\begin{abstract}
Fuzzy goal programming (FGP) method used in supplier selection process shows that decision maker preferences on each fuzzy goal are not yet considered. In order to accommodate those preferences, that are stated as weight on each fuzzy goal, and called weighted fuzzy goal programming (WFGP) method. Then, the developed method is utilized to solve international supplier selection problem. There would be 4 objective functions developed i.e. to minimize net cost, to minimize late delivery, to minimize net rejected material, as well as to maximize business relationship. Maximization of business relationship objective function is intended to obtain right suppliers related to it score. Those objective functions are optimized subject to total demand, maximum supplier capacity, total purchasing cost based on owner estimate, and minimum order requested by suppliers. Linguistic variables are used to measure criterions in business relationship factor. To do so, fuzzy analytic hierarchy process (FAHP) transforms that qualitative manner in linguistic variables to numerical number as a constant in business relationship objective function. Those proposed method provides enhanced solution that represent decision maker preferences than FGP. That is exhibited with equal relationship between weighted goals value and the output of those weighted goals.
\end{abstract}

Keywords: fuzzy goal programming, weighted, fuzzy analytic hierarchy process, supplier selection.

\section{PENDAHULUAN}

Permasalahan seleksi pemasok berkaitan dengan pemilihan pemasok yang benar dan pengalokasian kuotanya. Memilih pemasok yang benar merupakan keputusan krusial yang memiliki implikasi luas pada suatu rantai pasok. Penelitian yang berkaitan dengan pemilihan pemasok diantaranya dilakukan oleh Kumar dkk. (2004) menggunakan pendekatan furzy goal programming. Ketidakpastian dalam menentukan target dinyatakan pada furzy goal, dengan fungsi kendala deterministik. Çebi dan Bayraktar (2003) menggunakan pendekatan AHP dan lexicographic goal programming (LGP). Min (1993) menggunakan pendekatan multi-attribute utility technique (MAUT).
Barla (2003) menggunakan model matematika berbasiskan model seleksi multi atribut (multiatribute selection model, MSM). Youssef dkk. (1996) menggunakan model multi-attribute, cost-based, dan deterministik.

Pendekatan model fuzzy goal programming (FGP) sebagai alat bantu pengambilan keputusan pada dasarnya disusun berdasarkan model multi objectives linear programming (MOLP). Perbedaan antara linear programming (LP) dengan goal programming (GP) adalah pada goal programming dicirikan dengan adanya nilai target (aspirasi capaian) disebelah kanan persamaan fungsi objectives (Ignizio 1976; Zeleny 1981). Untuk menjadi model goal programming, nilai target pada

\footnotetext{
*Politeknik Perkapalan Negeri Surabaya ITS, E-mail: asinggihs@yahoo.com

‡ Jurusan Teknik Industri, FTI ITS, Jl. Arief Rahman Hakim, Surabaya (60111)
} 
setiap fungsi objectives diperoleh dengan cara menyelesaikan setiap objectives sebagai single objective sedangkan objectives lainnya diabaikan. Deviasi level aspirasi diberikan secara subyektif untuk masing-masing goal. Setelah itu disusun formulasi crisp berdasarkan fungsi keanggotaan setiap objective dan diselesaikan dengan single objective linear programming untuk mendapatkan nilai variabel keputusan. Terlihat bahwa fur:y goal programming tidak menunjukkan adanya preferensi pengambil keputusan yang menunjukkan tingkat kepentingan pengambil keputusan terhadap fungsi objectives seperti halnya pada preemptive goal programming.

Penelitian ini mengembangkan suatu metode untuk memberikan preferensi pengambil keputusan pada furzy goals. Model yang dikembangkan diaplikasikan pada permasalahan seleksi pemasok degan mengadaptasi model matematika yang dikembangkan oleh Kumar dkk. (2004). Dalam model ini ditambahkan faktor business relationship sebagai fungsi objective untuk menyeleksi pemasok. Faktor ini penting dimasukkan karena berisi kinerja pemasok yang dikaji oleh perusahaan secara administrasi dan teknis sebelum penentuan kuota. Dalam penelitian ini penilaian kinerja pemasok yang bersifat kualitatif akan dijadikan sebagai salah satu kriteria untuk menentukan kuota pemasok.

\section{KONSEP MODEL}

\subsection{Model LP untuk Seleksi Pemasok}

Memilih pemasok dan membagi perolehan alokasi kuota dengan mempertimbangkan faktor mutu, late delivery, harga, dan business relationship dimodelkan secara matematik sebagai berikut:

1. Mutu, meminimasi persentase cacat $r$ yang diperoleh dari pemasok ke $i$.
Minimalkan $Z_{2}=\sum_{i=1}^{n} l_{i}\left(x_{i}\right)$

3. Harga, minimasi harga pembelian dari sejumlah pemasok ke $i$ dengan harga penawaran $c$ :

Minimalkan $Z_{3}=\sum_{i=1}^{n} c_{i}\left(x_{i}\right)$

4. Business relationship, dimaksudkan agar kuota yang diberikan kepada pemasok sesuai dengan kualitas business relationship yang dijalin selama ini. Faktor ini tersusun atas 4 kriteria yang digunakan untuk menilai pemasok seperti pada gambar 1. Kriteria-kriteria jaminan mutu (quality assurance), pengalaman, kondisi finansial, dan komunikasi distrukturkan dengan mengacu berbagai penelitian diantaranya oleh Min (1994), serta Çebi dan Bayraktar (2003) yang dikomunikasikan dengan berbagai pihak dibidang pengadaan. Bentuk fungsi tujuannya adalah sebagai berikut:

Maksimasi $Z_{4}=\sum_{i=1}^{n} e_{i}\left(x_{i}\right)$

Fungsi kendala yang dipertimbangkan adalah:

1. Total demand material untuk periode produksi satu tahun.

$$
\sum_{i=1}^{n} x_{i}=D
$$

2. Jumlah material yang dipasok setiap rekanan tidak boleh melebihi kapasitas pasokan maksimum rekanan.

$$
x_{i} \leq Q_{i \max } \quad \forall i
$$

3. Harga pengadaan seluruh material berdasarkan owner estimate.

$\sum c_{i}\left(x_{i}\right) \leq c_{o e} . D$

4. Jumlah minimum unit pembelian yang disyaratkan oleh rekanan.

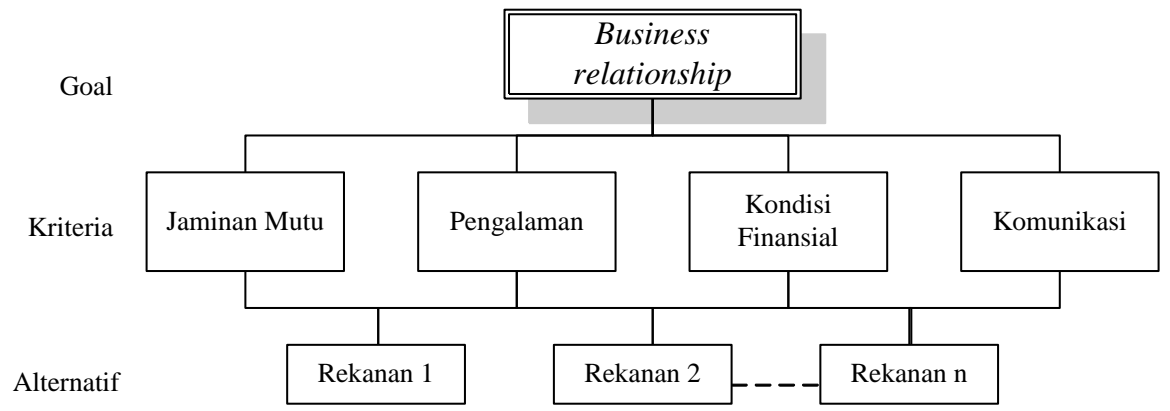

Gambar 1. Struktur hirarkhi faktor business relationship.

Minimalkan $Z_{1}=\sum_{i=1}^{n} r_{i}\left(x_{i}\right)$

2. Delivery, meminimasi $\%$ barang yang late delivery $l$ dari pemasok ke $i$.

$$
x_{i} \geq Q_{i \text { min }} \quad \forall i
$$

semua variabel $\geq 0$

dimana

$x_{i}=$ variabel keputusan menunjukkan perolehan alokasi pemasok ke $i$, 


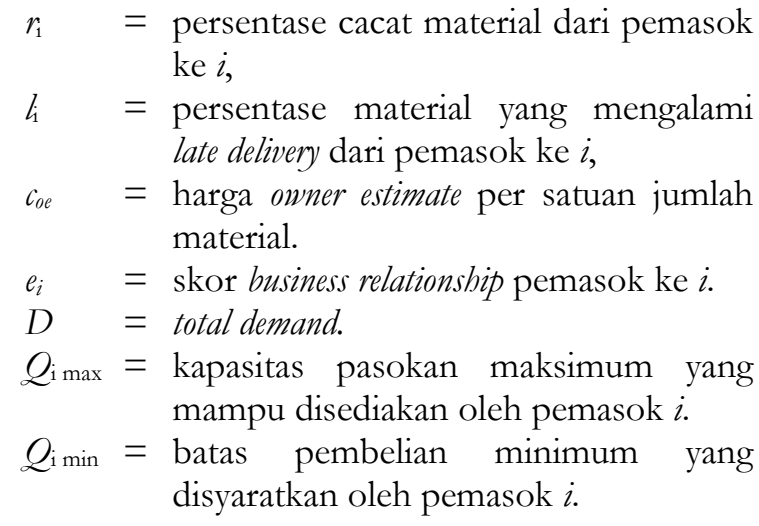

\subsection{Kuantifikasi Variabel Linguistik}

Struktur dan pengukuran elemen hirarkhi faktor business relationship pada gambar 1 disebut pendekatan analytic hierarchy process, AHP (Saaty 1988). Penggunaan metode furzy AHP (FAHP) disebabkan proses komputasi variabel linguistik, untuk pembandingan antar kriteria, adalah menggunakan bilangan fuz:y (Mon dkk. dalam Hsieh dkk. 2004). Sedangkan terminologi dan skala linguistik untuk penilaian alternatif pada kriteria yang bersesuaian berbeda dengan FAHP maka untuk mendapatkan performansi business relationship menggunakan pendekatan Furzy Multiple Criteria Decision Making, FMCDM (Hsieh dkk. 2004). Keluaran dari proses FMCDM adalah performansi nonfuzzy setiap alternatif.

Prosedur untuk menjelaskan bobot kriteria evaluasi dengan furzy AHP dapat diterangkan sebagai berikut:

a) Menyusun matriks perbandingan berpasangan diantara semua elemen/kriteria dalam dimensi sistem hirarkhi berdasarkan penilaian dengan variabel linguistik seperti persamaan (9).

b) Mendefinisikan rata-rata geometris furzy dan bobot fuzzy setiap kriteria menggunakan metoda Buckley (1985) pada persaman (10). $\tilde{a}_{\text {in }}$ adalah nilai perbandingan furzy dari kriteria $i$ ke kriteria $n, \tilde{r}_{i}$ adalah rata-rata geometris dari nilai perbandingan fuzæy kriteria $i$ terhadap setiap kriteria, dan $\tilde{w}_{i}$ adalah bobot fuz:y dari kriteria ke $i$.

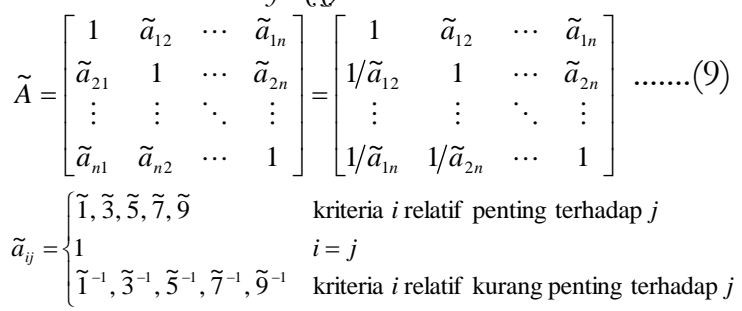
dimana

$$
\begin{aligned}
& \tilde{r}_{i}=\tilde{a}_{i 1} \otimes \tilde{a}_{i 2} \otimes \cdots \otimes \tilde{a}_{i n}, \\
& \tilde{w}_{i}=\tilde{r}_{i} \otimes\left(\tilde{r}_{1} \oplus \cdots \oplus \tilde{r}_{n}\right)^{-1}
\end{aligned}
$$

Dasar teori fuz:y multiple criteria decision making (FMCDM) untuk evaluasi dan pengukuran alternatif dikembangkan oleh Bellman dan Zadeh (1970) dalam pengambilan keputusan dalam lingkungan fuzzy. Teori FMCDM memiliki prosedur dan metode sebagai berikut:

a) Pengukuran Alternatif: Mengukur variabel linguistik untuk menunjukkan performansi kriteria dengan ungkapan "sangat baik", "baik", "biasa", "jelek", dan "sangat jelek" yang merupakan penilaian subyektif dari evaluator, dan setiap variabel linguistik diindikasikan dengan TFN. Evaluator dapat mendefinisikan sendiri skala linguistik untuk penilaian alternatif seperti pada Tabel 2 dan Gambar 3. Jika $\tilde{E}_{i j}$ adalah nilai performansi fuz:y alternatif $i$ pada kriteria $j$, maka kriteria evaluasi dinyatakan dalam:

$\tilde{E}_{i j}=\left(L E_{i j}, M E_{i j}, U E_{i j}\right)$

b) Furzy synthetic decision: Mengintegrasikan performansi fuzzy dengan bobot fuz:y pada kriteria yang bersesuaian.

$\widetilde{R}=\tilde{E} \circ \tilde{w}$

Pendekatan nilai furæy $\tilde{R}_{i}$ terwakili oleh $\tilde{R}_{i}=\left(L R_{i}, M R_{i}, U R_{i}\right) \quad$ merupakan nilai performansi sintetis dari alternatif $i$, dapat dihitung sebagai berikut:

$$
\begin{aligned}
& L R_{i}=\sum_{j=1}^{n} L E_{i j} \times L w_{j} ; \\
& M R_{i}=\sum_{j=1}^{n} M E_{i j} \times M w_{j} \\
& U R_{i}=\sum_{j=1}^{n} U E_{i j} \times U w_{j}
\end{aligned}
$$

c) Pe-ranking-an bilangan fuzzy menggunakan prosedur de-fur:y-fikasi dengan metoda Best Nonfuzay Performance (BNP).

$\mathrm{BNP}_{i}=\left[\left(U R_{i}-L R_{i}\right)+\left(M R_{i}-L R_{i}\right)\right] / 3 \quad \forall i$

\subsection{Variabel Linguistik}

Variabel linguistik adalah sebuah variabel dimana nilainya berupa kata-kata atau kalimat dalam bahasa alami atau buatan (Zadeh 1975). Teknik komputasinya menggunakan bilangan furyy seperti tabel 1 yang didefinisikan oleh Mon dkk (dalam Hsieh dkk, 2004). merupakan penggambaran triangular fuzzy number (TFN) dari Tabel 1 sedangkan Gambar 3 merupakan penggambaran TFN dari Tabel 2. 


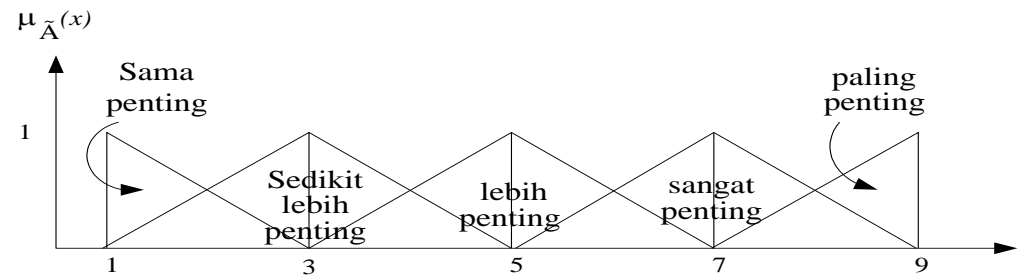

Gambar 2. Fungsi keanggotaan variabel linguistik untuk membandingkan kriteria.

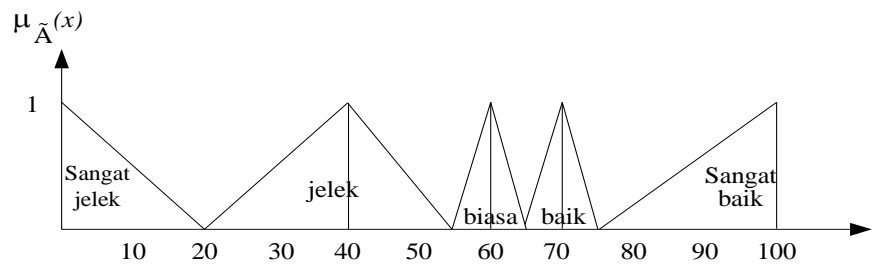

Gambar 3. Fungsi keanggotaan skala linguistik dari Tabel 2.

Tabel 1. Fungsi keanggotaan skala linguistik membandingkan kriteria.

\begin{tabular}{|c|c|c|}
\hline $\begin{array}{c}\text { Bilangan } \\
\text { Fuг:y }\end{array}$ & Skala Linguistik & $\begin{array}{c}\text { Skala } \\
\text { Bilangan } \\
\text { Furzy }\end{array}$ \\
\hline$\tilde{1}$ & Sama Penting (smp) & $(1,1,3)$ \\
\hline$\tilde{3}$ & $\begin{array}{l}\text { Sedikit Lebih } \\
\text { Penting (slp) }\end{array}$ & $(1,3,5)$ \\
\hline$\tilde{5}$ & Lebih Penting (lbp) & $(3,5,7)$ \\
\hline$\tilde{7}$ & $\begin{array}{l}\text { Sangat Penting } \\
\text { (sap) }\end{array}$ & $(5,7,9)$ \\
\hline$\tilde{9}$ & $\begin{array}{l}\text { Paling Penting } \\
\text { (pap) }\end{array}$ & $(7,9,9)$ \\
\hline
\end{tabular}

Tabel 2. Skala linguistik untuk penilaian kriteria setiap alternatif.

\begin{tabular}{ll}
\hline Skala Linguistik & Skala Bilangan Fu₹:Y \\
\hline Sangat Jelek (sjl) & $(0,0,20)$ \\
Jelek (jlk) & $(20,40,55)$ \\
Biasa (bia) & $(55,60,65)$ \\
Baik (bai) & $(65,70,75)$ \\
Sangat Baik (sba) & $(75,100,100)$ \\
\hline
\end{tabular}

\subsection{Keputusan Fuzzy}

Bellman and Zadeh (1970) menyatakan bahwa suatu keputusan fur:y merupakan fuz:y set dari alternatif-alternatif yang dihasilkan oleh interseksi antara goals dan constraints. Bila $D$ adalah keputusan, $G$ adalah furzy goals dan $C$ adalah furzy constraints maka hubungan ketiganya adalah:

$D=G \cap C$

dan fungsi keanggotaan:

$\mu_{\mathrm{D}}(x)=\min \left[\mu_{\mathrm{G}}(x), \mu_{\mathrm{C}}(x)\right]$

Keputusan optimal dapat diperoleh dengan:

$\mu_{\mathrm{D}} \mathrm{m}(x)=\max \mu_{\mathrm{D}}(x) \quad$ untuk $x \in \mathrm{K} \quad$.....(17)

dimana $\mathrm{K}$ adalah sekumpulan nilai di $X$ yang membuat nilai $\mu_{\mathrm{D}}$ mencapai nilai maksimum.
Besarnya tingkat penerimaan keputusan fur:y, baik yang bergerak ke batas bawah atau batas atas dari target, ditunjukkan oleh suatu fungsi keanggotaan sebagai berikut:

$$
\mu_{\left[f_{i}(\bar{x})\right]}= \begin{cases}{\left[\frac{f_{i}(\bar{x})-f_{i}^{\text {min }}}{\tilde{f}_{i}-f_{i}^{\text {min }}}\right],} & \text { jika } f_{i}^{\text {min }} \leq f_{i}(\bar{x}) \leq \tilde{f}_{i} \\ {\left[\frac{f_{i}^{\text {max }}-f_{i}(\bar{x})}{f_{i}^{\text {max }}-\tilde{f}_{i}}\right],} & \text { jika } \tilde{f}_{i} \leq f_{i}(\bar{x}) \leq f_{i}^{\text {max }} \\ 0, & \text { lainnya }\end{cases}
$$

dimana:

$\mu_{\left[f_{i}(\bar{x})\right]}=$ tingkat keanggotaan dari capaian fungsi objectives

$f_{i}(\bar{x})=$ persamaan fungsi objectives

$\tilde{f}_{i} \quad=$ furzy goal ke- $i$ hasil single objective linear programming

$f_{i}{ }^{\text {min }}=$ batas bawah deviasi furay goal ke- $i$

$f_{i}{ }^{\text {max }}=$ batas atas deviasi furzy goal ke- $i$

Bila dinyatakan dalam bentuk grafis maka fungsi keanggotaan tersebut adalah:

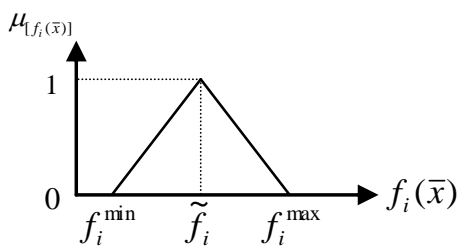

Gambar 4. Fungsi keanggotaan $f_{i}(\bar{x})$.

Pemecahan permasalahan optimasi fuz:y goal programming (fGP) adalah dengan mentransformasikan menjadi crisp goal programming (CGP) (Zimmermann 2000). Persyaratan terjadinya proses transformasi adalah 
dengan mendapatkan fungsi keanggotaan fungsi objectives $\mu_{\left[f_{i}(\bar{x})\right]}$ dengan persamaan (18). Langkah pemecahan ini menggunakan pendekatan Tiwari dkk (1986, dalam Ciptomulyono dan DOU, 2000) dimana formulasi FGP dipecahkan untuk mendapatkan perlengkapan keputusan, dan kemudian memaksimasikannya. Bentuk umum persamaan CGP adalah:

Max. $\lambda$

Sehingga memenuhi:

$\lambda \leq \mu_{\left[f_{i}(\bar{x})\right]}$

gi(xi) $<$ aj, $\quad$ j $=1,2, \ldots, J$

$\mathrm{hk}(\mathrm{xi})=\mathrm{bk}, \quad \mathrm{k}=1,2, \ldots, \mathrm{K}$

\subsection{Pembobotan pada Fuzzy Goal}

Pembobotan ini menunjukkan level aspirasi pengambil keputusan terhadap alternatif goals. Keputusan furzy dengan goals terbobot menurut Yager (1978, dalam Zimmermann 2000)dapat dituliskan sebagai berikut:

$$
\tilde{D}=\tilde{G}_{1}^{w_{1}} \cap \tilde{G}_{2}^{w_{2}} \cap \cdots \cap \widetilde{G}_{m}^{w_{m}}
$$

dimana $w_{\text {m }}$ merupakan bobot furzy goal $\tilde{G}$ ke $m$ yang bisa diperoleh dengan metode AHP. Dikarenakan pencapaian fuгzy goal $\tilde{G}_{m}$ dengan alternatif yang terpilih $\bar{x}$ ditunjukkan dengan suatu fungsi keanggotaan $\mu_{\left[G_{m j}(\bar{x})\right]}$, maka mengacu persamaan (16) keputusan fuz:y dengan goal terbobot $w$ untuk goal ke $m$ adalah nilai terendah dari keanggotaan fuz:y goal dipangkatkan bobot $w$.

\section{LANGKAH PEMECAHAN}

\subsection{Kuantifikasi Data Kualitatif}

a) Data yang bersifat kualitatif adalah faktor business relationship pemasok yang berisi penilaian kriteria dan penilaian alternatif pada kriteria yang bersesuaian.

b) Untuk keperluan evaluasi pembobotan, data ini disusun dalam struktur hirarkhi seperti pada gambar 1.

c) Pengukuran data dilakukan dengan variabel linguistik. Skala linguistik yang diterjemahkan kedalam bilangan fuz:y digunakan untuk proses komputasi. Penggunaan bilangan fur:y yang mewakili variabel linguistik merupakan langkah awal kuantifikasi sifat kualitatif.

d) Penilaian tingkat kepentingan kriteria disusun menjadi matriks perbandingan berpasangan seperti pada persamaan (9).

e) Menghitung rata-rata fur:y dan bobot fuz:y dengan persamaan (10). f) Untuk memperoleh ranking kriteria dilakukan dengan de-furzy-fikasi mengacu persamaan (14).

g) Bobot fuzzy dari langkah 5 diagregasikan dengan fuz:y performance value untuk mendapatkan furay synthetic decision. Agregasi ini mengacu pada persamaan (12).

h) Untuk memperoleh performansi business relationship maupun pemasok furay synthetic decision di de-fuz:y-fikasi dengan persamaan (14).

i) Performansi pemasok pada faktor business relationship selanjutnya digunakan sebagai fungsi objectives responsveness pada weighted-furzy goal programming.

\subsection{Komputasi weighted-fuzzy goal} programming

a) Data kuantitatif mutu, harga barang, late delivery dan performansi business relationship setiap pemasok dijadikan sebagai fungsi objectives persamaan multi objectives linear programming. Persamaan fungsi objectives dan kendala ditunjukkan persamaan (1) sampai (8).

b) Persamaan tersebut diselesaikan dengan metode single objectives linear programming dengan menyelesaikan satu persatu fungsi objective untuk mendapatkan nilai target furay goal.

c) Menggambarkan deviasi disekitar nilai fur:y goals seperti pada gambar 4 dimana nilai deviasi diberikan oleh pengambil keputusan.

d) Menyusun dan menyelesaikan persamaan crisp seperti pada persamaan (9) sampai (10)

e) Mencari tingkat keanggotaan $x_{1}$ di setiap furay goals (furzy goal mutu, furay goal late delivery, furzy goal harga, dan furay goal business relationship).

f) Bobot prioritas yang menunjukkan preferensi pengambil keputusan terhadap setiap furzy goal diolah dengan AHP untuk memperoleh nilai bobot yang konsisten.

g) Bobot prioritas terhadap fuz:y goal digunakan untuk memperoleh nilai keanggotaan keputusan fuz:y terbobot berdasarkan persamaan (21).

h) Nilai keanggotaan keputusan fur:y pada goal yang terbobot dijadikan fungsi kendala pada persamaan crisp.

i) Dengan perubahan bobot pada setiap furzy goal akan dilihat optimalitas keputusan fur:y dan bagaimana pengaruhnya terhadap alokasi kuota yang diperoleh oleh setiap pemasok. 
Efektifitas metode yang dikembangkan diuji coba dengan data material hasil tambang yang diimpor dari berbagai negara pada Tabel 3, penilaian faktor business relationship pada Tabel 4, dan 5. Total demand material ini sebesar 1.600.000 $\mathrm{mt} /$ tahun dengan harga owner estimate 42,19 $\mathrm{USD} / \mathrm{mt}$ FOB destination.

Bila dari Tabel 4 dan 5 dihitung dengan metode FAHP dan FMCDM (dalam Hsieh dkk. 2004)

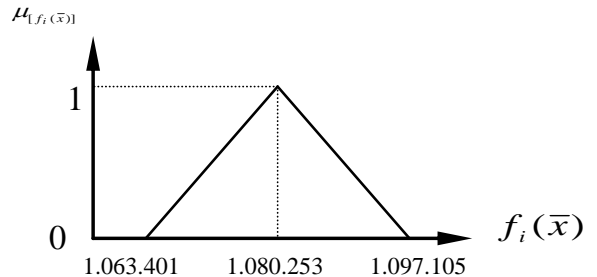

Gambar 5. Fungsi keanggotaan objective mutu.

Tabel 3. Data pemasok, alokasi dan harga.

\begin{tabular}{|c|c|c|c|c|c|c|}
\hline Pemasok & $\begin{array}{c}\text { alokasi } \\
(\mathrm{mt})\end{array}$ & $\begin{array}{c}\text { Harga } \\
(\mathrm{USD} / \mathrm{mt})\end{array}$ & $\begin{array}{c}\text { Kandungan } \\
\text { mineral utama } \\
(\%)\end{array}$ & $\begin{array}{c}\text { Pasokan } \\
\text { maksimal } \\
(\mathrm{mt} / \text { tahun })\end{array}$ & $\begin{array}{c}\text { Order } \\
\text { minimum } \\
(\mathrm{mt})\end{array}$ & $\begin{array}{c}\text { Late } \\
\text { delivery } \\
(\%)\end{array}$ \\
\hline 1 & 240.000 & 41,76 & 32,00 & 900.000 & 7.000 & - \\
\hline 2 & 520.000 & 41,80 & 32,17 & 3.000 .000 & 12.000 & - \\
\hline 3 & 360.000 & 42,00 & 32,49 & 1.800 .000 & 8.000 & - \\
\hline 4 & 480.000 & 41,85 & 32,20 & 2.400 .000 & 7.000 & - \\
\hline
\end{tabular}

$\mathrm{mt}=$ metrik ton

Tabel 4. Hasil penilaian kriteria pada faktor business relationship.

\begin{tabular}{|l|c|c|c|c|}
\hline \multicolumn{1}{|c|}{ Kriteria } & Jaminan mutu & Pengalaman & Finansial & Komunikasi \\
\hline Jaminan mutu & 1 & & $l b p$ & pap \\
\hline Pengalaman & S/p & 1 & pap & sap \\
\hline Finansial & & & 1 & slp \\
\hline Komunikasi & & & & 1 \\
\hline
\end{tabular}

Tabel 5. Penilaian kriteria setiap pemasok dengan variabel linguistik.

\begin{tabular}{|c|c|c|c|c|}
\hline \multirow{2}{*}{ Pemasok } & \multicolumn{4}{|c|}{ Kriteria } \\
\cline { 2 - 5 } & Jaminan mutu & Pengalaman & Finansial & Komunikasi \\
\hline 1 & Baik & Baik & Baik & Baik \\
\hline 2 & Sangat baik & Sangat baik & Baik & Baik \\
\hline 3 & Sangat baik & Sangat baik & Baik & Sangat baik \\
\hline 4 & Sangat baik & Baik & Baik & Sangat baik \\
\hline
\end{tabular}

diperoleh nilai performansi setiap pemasok $\mathrm{BNP}_{\text {pemasok } 1}=323,6477, \mathrm{BNP}_{\text {pemasok } 2}=433,3665$, $\mathrm{BNP}_{\text {pemasok3 }}=431,2791, \mathrm{BNP}_{\text {pemasok4 }}=$ 337,8056, selanjutnya digunakan sebagai konstanta pada fungsi tujuan maksimasi business relationship.

Penyelesaian model MOLP persamaan (1) sampai (8) menghasilkan: $\mathrm{Z}_{1}=1.080 .253, \mathrm{Z}_{3}=$ 66.845.950, dan $Z_{4}=691.931 .700$. Deviasi yang diberikan pada setiap furay goals adalah 1,56\% untuk mutu, 0,95\% untuk harga dan 15\% untuk business relationship. Dengan deviasi tersebut maka dapat digambarkan fungsi keanggotaan setiap objectives pada gambar 5, 6, dan 7 .

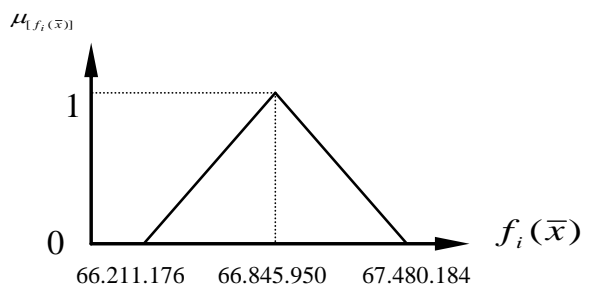

Gambar 6. Fungsi keanggotaan objective harga.

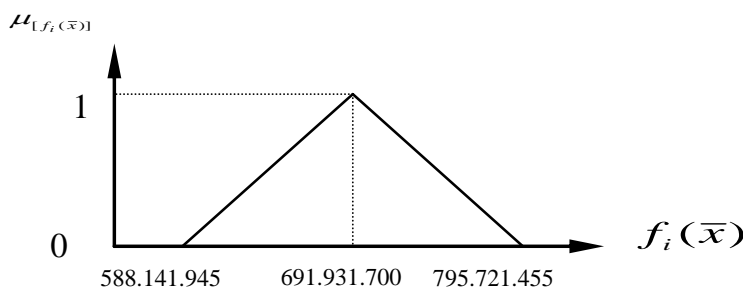

Gambar 7. Fungsi keanggotaan objective business relationship. 
Berdasarkan gambar fungsi keanggotaan diatas maka dapat disusun persamaan crisp:

Maksimalkan $\lambda$

Untuk memenuhi:

$$
\begin{aligned}
& \lambda \leq 0,00004035 \mathrm{x}_{1}+0,00004025 \mathrm{x}_{2}+0,00004006 \mathrm{x}_{3} \\
&+0,00004023 \mathrm{x}_{4}-63,103 \\
& \lambda \leq-\left(0,00004035 \mathrm{x}_{1}+0,00004025 \mathrm{x}_{2}+0,00004006 \mathrm{x}_{3}\right. \\
&\left.+0,00004023 \mathrm{x}_{4}\right)+65,103 \\
& \lambda \leq\left(0,00006247 \mathrm{x}_{1}+0,00006253 \mathrm{x}_{2}+0,00006283 \mathrm{x}_{3}\right. \\
&\left.+0,000062615 \mathrm{x}_{4}\right)-104,396 \\
& \lambda \leq-\left(0,00006247 \mathrm{x}_{1}+0,00006253 \mathrm{x}_{2}+0,00006283 \mathrm{x}_{3}\right. \\
&\left.+0,000062615 \mathrm{x}_{4}\right)+106,396 \\
& \lambda \leq\left(0,00000312 \mathrm{x}_{1}+0,00000418 \mathrm{x}_{2}+0,00000416 \mathrm{x}_{3}\right. \\
&\left.+0,00000325 \mathrm{x}_{4}\right)-5,67 \\
& \lambda \leq-\left(0,00000312 \mathrm{x}_{1}+0,00000418 \mathrm{x}_{2}+0,00000416 \mathrm{x}_{3}\right. \\
&\left.+0,00000325 \mathrm{x}_{4}\right)+7,67 \\
& \mathrm{x}_{1}+ \mathrm{x}_{2}+\mathrm{x}_{3}+\mathrm{x}_{4}=1.600 .000 \\
& \mathrm{x}_{1}<= 900.000 \\
& \mathrm{x}_{2}<= 3.000 .000 \\
& \mathrm{x}_{3}<= 1.800 .000 \\
& \mathrm{x}_{4}<= 2.400 .000 \\
& 41,76 \mathrm{x}_{1}+41,8 \mathrm{x}_{2}+42 \mathrm{x}_{3}+41,85 \mathrm{x}_{4}<=67.504 .000 \\
& \mathrm{x}_{1}>= 7.000 \\
& \mathrm{x}_{2}>= 12.000 \\
& \mathrm{x}_{3}>= 8.000 \\
& \mathrm{x}_{4}>= 7.000 \\
& \text { dengan } \mathrm{x}_{\mathrm{i}}>=0 \\
& \mathrm{Pe}
\end{aligned}
$$

Penyelesaian model diatas menghasilkan $\lambda=$ $0,7932, x_{1}=7.000, x_{2}=1.100 .852, x_{3}=$ 485.148, $x_{4}=7.000$,

Perolehan alokasi setiap pemasok dicari dengan langkah-langkah sebagai berikut:

1. Hasil penyelesaian model diatas dimasukkan ke dalam setiap fungsi objectives persamaan (1) sampai (4) dan hasilnya dimasukkan persamaan (18) untuk mencari nilai keanggotaan dengan tetap mengacu gambar 5 sampai 7 sehingga diperoleh nilai keanggotaan setiap goals adalah $\mu_{f_{1}(\bar{x})}=$ 0,7932, $\mu_{f_{3}(\bar{x})}=0,7932$, dan $\mu_{f_{4}(\bar{x})}=0,99$.

2. Mencari nilai bobot dengan metode AHP:

a. Mutu cukup penting dibandingkan harga (skala = 3), mutu mutlak penting dibandingkan business relationship (skala = 9) dan harga lebih penting dibandingkan business relationship (skala $=5$ ). Diperoleh bobot goal mutu $w_{1}=0,669$, bobot goal harga $w_{3}=0,267$, dan bobot goal business relationship $w_{4}=0,064$.

b. Harga cukup penting dibandingkan mutu (skala $=3$ ), harga sangat penting dibandingkan business relationship (skala = 7), dan mutu cukup penting dibandingkan business relationship (skala $=3$ ). Diperoleh bobot goal mutu $w_{1}=0,243$, bobot goal harga $w_{3}=0,669$, dan bobot goal business relationship $w_{4}=0,088$.

c. Business relationship cukup penting dibandingkan mutu (skala = 3), business relationship lebih penting dibandingkan harga (skala $=5$ ), mutu cukup penting dibandingkan harga (skala $=3$ ). Diperoleh bobot goal mutu $w_{1}=0,26$, bobot untuk goal harga $w_{3}=0,11$, dan bobot goal business relationship $w_{4}=0,63$.

3. Sehingga nilai goal mutu terbobot $\mu_{\mathrm{D}}(x)=$ 0,856, nilai goal harga terbobot $\mu_{\mathrm{D}}(x)=$ 0,856. Sedangkan goal business relationship terbobot jatuh pada goal mutu dengan $\mu_{\mathrm{D}}(x)$ $=0941$

4. Hasil perolehan alokasi pada setiap goal

\begin{tabular}{|c|c|c|c|c|c|c|}
\hline \multirow{2}{*}{$\begin{array}{l}\text { Pemas } \\
\text { ok }\end{array}$} & \multirow{2}{*}{$\begin{array}{l}\text { Harga } \\
\text { (USD) }\end{array}$} & \multirow{2}{*}{$\begin{array}{l}\text { Mineral } \\
\text { utama }(\%)\end{array}$} & \multicolumn{4}{|c|}{ Alokasi (mt) } \\
\hline & & & FGP $(\mu=0,7932)$ & $\begin{array}{l}\text { WFGP-mutu } \\
\text { dipentingkan }\end{array}$ & $\begin{array}{l}\text { WFGP-harga } \\
\text { dipentingkan }\end{array}$ & $\begin{array}{l}\text { WFGP-bus.rel } \\
\text { dipentingkan }\end{array}$ \\
\hline 1 & 2 & 3 & 4 & 5 & 6 & 7 \\
\hline 1 & 41,76 & 32,00 & 7.000 & 7.000 & 7.000 & 7.000 \\
\hline 2 & 41,80 & 32,17 & 1.100 .852 & 767.834 & 1.302 .562 & 320.366 \\
\hline 3 & 42,00 & 32,49 & 485.148 & 818.166 & 283.438 & 1.265 .634 \\
\hline 4 & 41,85 & 32,20 & 7.000 & 7.000 & 7.000 & 7.000 \\
\hline \multicolumn{3}{|c|}{ Kandungan mineral (mt) } & $516.262,67$ & $517.328,33$ & $515.617,2$ & $518.760,23$ \\
\hline \multicolumn{3}{|c|}{ Harga pembelian (USD) } & $66.977 .099,60$ & $67.043 .703,2$ & $66.936 .967,67$ & $67.133 .196,8$ \\
\hline
\end{tabular}
terbobot adalah:

\section{ANALISA HASIL PENELITIAN}

Tabel 6 kolom 5 menjelaskan nilai untuk goal mutu dibobot lebih penting dari goals lainnya dengan nilai keanggotaan keputusan furzy pada goal mutu $=0,856$ menghasilkan kandungan mineral 517.328,33 mt mengalami kenaikan sebesar 0,206 \% walaupun diimbangi juga dengan kenaikan harga pembelian sebesar 0,099\%. Karena mutu lebih dipentingkan dari goals lainnya maka pemasok dengan mutu yang lebih baik memperoleh alokasi yang lebih banyak yaitu pemasok 3 dan mengurangi perolehan pemasok lain. Sehingga pemasok 3 mengalami kenaikan sebesar 68,64\% dari perolehan yang dihitung dengan metode FGP. Sedangkan pemasok 2 mengalami penurunan perolehan sebesar 30,25\% dari perolehan yang dihitung dengan metode FGP. Dengan mutu lebih dipentingkan terlihat juga kandungan mineral yang diperoleh.

Tabel 6. Hasil penyelesaian dengan metode WFGP. 
Penyelesaian dengan metode WFGP untuk harga lebih dipentingkan, Tabel 6 kolom 6, dengan nilai keanggotaan keputusan furay pada goal harga $=0,856$ memberikan solusi layak pada harga pembelian $f_{3}(\bar{x})=66.936 .967,67$ USD. Karena harga lebih dipentingkan dari goals lainnya maka pemasok 2 dengan harga yang lebih rendah akan memperoleh alokasi yang lebih banyak dan mengurangi perolehan pemasok lain. Perubahan perolehan alokasi terjadi pada pemasok 2, yaitu mengalami kenaikan perolehan sebesar $18,32 \%$ dari perolehan yang dihitung dengan metode FGP. Sedangkan pemasok 3 dengan harga lebih mahal mengalami penurunan perolehan alokasi sebesar 41,58\% dari perolehan yang dihitung dengan metode FGP. Dengan komposisi hasil perolehan alokasi seperti pada Tabel 6, penurunan harga pembelian sebesar $0,0006 \%$ akan mengakibatkan penurunan kandungan mineral yang akan diperoleh menjadi sebesar $0,125 \%$.

Penyelesaian dengan metode WFGP untuk business relationship lebih dipentingkan, Tabel 6 kolom 7, dengan nilai keanggotaan keputusan furzy pada goal mutu $=0,941$ dapat didefinisikan:

a) Pada penyelesaian dengan metode FGP nilai keanggotaan business relationship sebesar 0,99 memiliki pengertian bahwa proses pemilihan pemasok sudah menghasilkan capaian yang "satisfied" dimana pemasok dengan nilai business relationship yang terbaik mendapatkan perolehan alokasi yang terbesar.

b) Karena pada goal mutu terdapat fungsi minimasi persentase cacat maka pemasok dengan persentase cacat terendah atau memiliki mutu terbaik akan memperoleh alokasi yang lebih banyak. Hasilnya adalah pemasok 3 dengan mutu yang lebih baik memperoleh kenaikan alokasi sebesar $160,88 \%$ dari perolehan yang diselesaikan dengan metode FGP. Sedangkan pemasok 2 dengan mutu lebih rendah mengalami penurunan perolehan sebesar $70,90 \%$ dari perolehan yang diselesaikan deng metode FGP. Dengan goal mutu lebih dipentingkan maka jumlah cacat adalah $f_{1}(\bar{x})$ sebesar 1.081.239,77 $\mathrm{mt}$ atau kandungan mineral utama sebesar 518.760,23 mt.

\section{SIMPULAN}

Metode weighted-furzy goal programming (WFGP) menghasilkan solusi yang lebih mewakili preferensi pengambil keputusan bila dibandingkan dengan metode FGP. Dimana preferensi pengambil keputusan yang dinyatakan dalam nilai bobot. Nilai yang dipangkatkan pada goals dapat menunjukkan hubungan yang selaras antara nilai goals terbobot dengan capaian aspirasi pada goals terbobot. Semakin besar nilai goals terbobot maka semakin naik capaian aspirasi pada goals terbobot tersebut. Akibatnya pemasok dengan value yang lebih baik pada goals terbobot akan mendapatkan perolehan yang semakin naik.

Pembobotan yang diberikan pada faktor business relationship akan membuat keputusan furiy jatuh pada goal mutu terbobot. Karena nilai keanggotaan faktor business relationship sebesar 0,99 (satisfied) menunjukkan bahwa tingkat perolehan pasokan pemasok sesuai dengan nilai business relationship yang diperoleh.

Penilaian yang bersifat kualitatif pada faktor business relationship dikuantifikasi menggunakan metode furay analytic bierarchi process (FAHP) dengan mentransformasi skala linguistik kedalam bilangan fuz:y.

Penelitian ini dapat dikembangkan dengan mempertimbangkan sifat kesamaran setiap kriteria untuk setiap alternatif pemasok. Pengembangan lain yang dapat dilakukan adalah dengan symmetrical fursy linear programming, dimana baik fungsi objectives maupun constrints bersifat furzy.

\section{DAFTAR ACUAN}

Barla, S.B. (2003), 'A Case Study of Supplier Selection for Lean Supply by Using a Mathematical Model', Logistic Information Management, 16, pp. 451-459.

Bellman, R.E. dan Zadeh, L.A. (1970), Decision-Making in a Fuzzy Environment, In: Fuzzy Sets and Applications: Selected Papers by L.A. Zadeh, (1987), eds: R.R. Yager, S. Ovchinnikov, R.M. Tong, H.T. Nguyen., John Wiley \& Sons, USA, pp. 53-79.

Buckley, J.J. (1985), 'Ranking Alternatives Using Fuzzy Numbers', Fuzzy Sets and Systems, 15, pp. 21-31.

Çebi, F. dan Bayraktar, D. (2003), 'An Integrated Approach for Supplier Selection', Logistic Information Managemen, 16, pp. 395-400.

Ciptomulyono, U. dan DOU, H. (2000), Model Fuzzy Goal Programming untuk Penetapan Pembobotan Prioritas dalam Metode Proses Analisis Hirarkhis (AHP), Majalah IPTEK, 11, pp. 19-29.

Hsieh, T.Y., Lu, S.T. dan Tzeng, G.H. (2004), 'Fuzzy MCDM Approach for Planning and Design Tenders Selection in Public Office Building', International Journal of Project Management, (articel in press). 
Ignizio, J.P. (1976), Goal Programming and Extensions, Lexington Books, Massachusetts.

Kumar, M., Vrat, P. dan Shankar, R. (2004), 'A Fuzzy Goal Programming Approach for Vendor Selection Problem in a Supply Chain', Computers \& Industrial Engineering, 46, pp. 69-85.

Min, H. (1993), 'International Supplier Selection: A Multi-attribute Utility Approach, International Journal of Phisical Distribution \& Logistic Managemen, 5, pp. 24-33.

Saaty, T.L. (1988), Multiple Criteria Decision Making: The Analytic Hierarchy Process, 2nd edition, USA.

Tabucanon, M.T. (1988), Multiple Criteria Decision Making in Industry, Elsevier, New York.

Youssef, M.A., Zairi, M. dan Mohanty, B. (1996), 'Supplier Selection in an Advenced Manufacturing Technology Environment: An Optimization Model', Benchmarking for Quality Management \& Technology, 3, pp. 60-72.
Zadeh, L.A. (1975), The Concept of Linguistic Variable and its Application to Approximate Reasoning-I, In: Fuzzy Sets and Applications: Selected Papers by L.A. Zadeh, (1987), eds: R.R. Yager, S. Ovchinnikov, R.M. Tong, H.T. Nguyen., John Wiley \& Sons, USA, pp. 219-269.

Zimmermann, H.J. (2000), Fuzzy Set Theoryand its Application, 3rd edition, Kluwer Academic Publishers, USA.

Zeleny, M. (1981), 'Technical Note: The Pros and Cons of Goal Programming', Computer \& Operation Research, 4, pp. 357-359.

Diterima: 08 Oktober 2005

Disetujui untuk diterbitkan: 12 September 2006 